\title{
Trypsin hydrolysis of whey protein concentrates: Characterization using multivariate data analysis
}

\author{
M.V.T. Mota ${ }^{\text {a }}$, I.M.P.L.V.O. Ferreira ${ }^{\mathrm{a}, *}$, M.B.P. Oliveira ${ }^{\mathrm{a}}$, C. Rocha ${ }^{\mathrm{b}}$, \\ J.A. Teixeira ${ }^{c}$, D. Torres ${ }^{d}$, M.P. Gonçalves ${ }^{d}$ \\ a REQUIMTE, Serviço de Bromatologia, Faculdade de Farmácia, Universidade do Porto, Rua Aníbal Cunha, 164, 4050-047 Porto, Portugal \\ ${ }^{\mathrm{b}}$ Escola Superior de Tecnologia e Gestão, Instituto Politécnico de Viana do Castelo, Apartado 574, 4900 Viana do Castelo, Portugal \\ ${ }^{\mathrm{c}}$ Centro de Engenharia Biológica - IBQF, Universidade do Minho, Campus de Gualtar 4710-057 Braga, Portugal \\ ${ }^{\mathrm{d}}$ REQUIMTE, Departamento de Engenharia Química, Faculdade de Engenharia, Universidade do Porto, \\ Rua Dr. Roberto Frias, 4200-465 Porto, Portugal
}

Received 4 May 2004; received in revised form 7 January 2005; accepted 30 January 2005

\begin{abstract}
Hydrolysis of whey protein concentrates (WPCs) was performed using trypsin under different combinations of temperatures and $\mathrm{pH}$ values in a total of three experiments, namely experiment $\mathrm{A}$ at $37^{\circ} \mathrm{C}$ and $\mathrm{pH} 8$, experiment $\mathrm{B}$ at $37^{\circ} \mathrm{C}$ and $\mathrm{pH} 9$, and experiment $\mathrm{C}$ at $50^{\circ} \mathrm{C}$ and $\mathrm{pH}$ 8. Monitorization of the degradation of native whey proteins and the peptide formation throughout hydrolysis was performed by reverse phase HPLC/UV. Seven main peptides were separated according to their polarity and numbered from T1 to T7. In general a difference was observed between rate of hydrolysis of $\alpha$-lactalbumin and $\beta$-lactoglobulin; in the former case hydrolysis was complete by $15 \mathrm{~min}$ in experiments $\mathrm{B}$ and $\mathrm{C}$ and by $120 \mathrm{~min}$ in experiment $\mathrm{A}$, whereas in the later case the rate of hydrolysis was much slower.

ANOVA analysis, performed to assess whether the average values obtained for the three experiments conducted to statistically different results for each variable ( $\%$ of $\beta$-lactoglobulin degradation and $\%$ of peptides $\mathrm{T} 1$ to T7), showed significant differences between experiments A and C. However, between A and B and between B and C no significant differences were observed. Principal Component Analysis evidenced the time period at which similarities and/or differences between experiments were observed. Additionally, a mathematical equation for the degradation of $\beta$-lactoglobulin as a function of hydrolysis time was established and some peptides were correlated with their parental protein using linear regression analysis.
\end{abstract}

(C) 2005 Elsevier Ltd. All rights reserved.

Keywords: Whey proteins; Enzymatic hydrolysis; RP-HPLC

\section{Introduction}

Whey is a waste product from cheese industry. However, it contains proteins ( $\alpha$-lactalbumin and $\beta$-lactoglobulin) that have a high nutritional value (because of

\footnotetext{
${ }^{*}$ Corresponding author. Tel.: +351 22207 8929; fax: +351 22200 3977.

E-mail address: isabel.ferreira@ff.up.pt (I.M.P.L.V.O. Ferreira).
}

their relatively high content of essential amino acids) and are an important source of bioactive sequences (Clare \& Swaisgood, 2000; FitzGerald \& Meisel, 2000; Korhonen, 2002; Leppala, Rokka, \& Korhonen, 1998; Shah, 2000).

Growing interest has been shown in recent years in bioactive peptides derived from whey proteins. Such peptides have been found to exert various bioactivities both in vitro and in vivo, for example protective functions, 
regulation of digestion and nutrient uptake, and metabolic or physiological regulation of the body. Bioactive peptides are inactive within the sequence of the parent protein and can be released in three ways: by enzymatic hydrolysis with digestive enzymes; by fermentation of milk with proteolytic starters and through the action of enzymes produced by proteolytic microorganisms (Foegeding, Davis, Doucet, \& McGuffey, 2002; Silvestre, 1997).

$\beta$-Lactoglobulin, especially, is responsible for most of the bioactive properties of whey protein products (Chen, Swaisgood, \& Foegeding, 1994; Madsen, Ahmt, Otte, Halkier, \& Qvist, 1997; Otte, Ju, Faergemand, Lomholt, \& Qvist, 1996). Thus, hydrolysates of these proteins can be added to special food with increased value, as enzymatic hydrolysis originates peptides that increase its nutritional properties (digestibility and bioactivity). Besides these properties, whey proteins hydrolysates can also be used for a variety of functional applications, once they can act as gelling agents, emulsifiers or foaming agents (Foegeding et al., 2002; Otte et al., 1996), depending on the nature of the peptides produced and the degree of hydrolysis.

Hydrolysates peptide composition, and consequently their properties, is dependent of protein and enzyme used, as well as, on hydrolysis conditions (temperature, $\mathrm{pH}$, enzyme to substrate ratio and reaction time). Hydrolysates can be characterized according to several molecular characterization methods, which reflect their molecular properties. Until recently, fractionation was often performed rather arbitrarily. With new analytical and statistical techniques it has become possible to analyse a multitude of data simultaneously, which allows to investigate correlations between several hydrolysate characteristics.

The present study was undertaken to characterize hydrolysis of whey protein concentrates (WPCs), using trypsin. Hydrolyses were performed at two temperatures and two $\mathrm{pH}$ (in three different experiments). Monitoring was carried out during several hours by reverse phase HPLC/UV (RP-HPLC/UV) to follow the time course of the degradation of native whey proteins and the formation of peptides, which were separated according to their polarity. It is described that tryptic peptides from whey proteins present great interest in food industry owing to its emulsifying, interfacial and gelation properties. In this paper, we focused on the statistical treatment necessary to: assess whether the different experiments conducted to statistically different results for those variables evaluated; find out the kinetics of degradation of $\beta$-lactoglobulin (a correlation equation for the degradation of $\beta-\mathrm{Lg}$ vs. time of hydrolysis); try to correlate peptides with their parental protein; study similarities and differences between samples analysed for the three experiments.

\section{Experimental}

\subsection{Substrate and enzymes}

A commercial spray dried whey protein concentrate with $80 \%$ wt of protein was used as substrate.

Trypsin from porcine pancreas with an activity of 1020 BAEE U/mg protein, was obtained from Sigma Chemical Co.

\subsection{Hydrolysis}

Enzymatic hydrolysis were performed in a $0.5 \mathrm{~L}$ stirred, tank-type, batch reactor equipped with $\mathrm{pH}$ and temperature control.

Three different experiments (designated A, B and C) were performed, to evaluate the influence of $\mathrm{pH}$ and temperature on tripsin whey protein hydrolysates. Experiment $\mathrm{A}$ was conducted at $37^{\circ} \mathrm{C}$ and $\mathrm{pH} 8$, whereas experiment $\mathrm{B}$ was made at the same temperature and $\mathrm{pH}$ 9. Finally, experience $\mathrm{C}$ was carried out at $50^{\circ} \mathrm{C}$ and $\mathrm{pH}$ 8. The ratio enzyme/substrate was maintained constant. For each experiment, samples were collected, before (time zero) and during the hydrolysis of bovine milk whey protein concentrate, at variable intervals of time, during more than $5 \mathrm{~h}$. The reaction was stopped by immersion of the samples in a water bath at $90^{\circ} \mathrm{C}$ and afterwards, stored at $-20^{\circ} \mathrm{C}$. Prior to analysis by RP-HPLC, samples were left at room temperature and diluted with ultra purified water.

\subsection{Chromatographic analysis}

RP-HPLC/UV was used for the separation of $\beta$-lactoglobulin $(\beta-\mathrm{Lg}), \alpha$-lactalbumin $(\alpha-\mathrm{La})$ and the resulting peptides from hydrolysis. An analytical HPLC unit (Jasco) with a Chrompack P-300-RP column was used. Gradient elution was carried out with a mixture of two solvents (solvent A: $0.1 \%$ trifluoroacetic acid (TFA) in water and solvent B: $0.1 \%$ TFA in $80 \%$ aqueous acetonitrile, $[\mathrm{v} / \mathrm{v}])$. Proteins and peptides were eluted as follows: $0-1 \mathrm{~min}, 90 \% \mathrm{~A} ; 1-10 \mathrm{~min}, 90-80 \% \mathrm{~A} ; 10$ $15 \mathrm{~min}, 80-75 \%$ A; $15-20 \mathrm{~min}, 75-60 \%$ A; 20-30 min, $60-50 \%$ A; 30-33 min, 50-40\% A; 33-36 min, 40-30\% A; 36-39 min, 30-20\% A; 39-41 min, 20-0\% A.

The flow-rate was $0.5 \mathrm{ml} / \mathrm{min}$. The column was used at ambient temperature and detection at $215 \mathrm{~nm}$. Total run time was $50 \mathrm{~min}$.

Purified bovine standards of $\beta$-lactoglobulin $(\beta-\mathrm{Lg})$ and $\alpha$-lactalbumin $(\alpha-\mathrm{La})$ were supplied by Sigma Chemical Co and dissolved in ultra purified water. Under the conditions used, the major whey proteins, $\alpha$-La and $\beta-\mathrm{Lg}$ fractions were well separated and exhibited retention times of 34.5 and $37.5 \mathrm{~min}$, respectively. The chromatographic system was calibrated by the external standard method with solutions that contained bovine 
$\alpha-\mathrm{La}$ in the range of $0.039-1.0 \mathrm{mg} / \mathrm{mL}$ and bovine $\beta-\mathrm{Lg}$ in the range of $0.0039-1.0 \mathrm{mg} / \mathrm{mL}$.

\subsection{Statistical analyses}

Statistical analyses were all performed with SPSS for Windows version 11.5 (SPSS Inc., Chicago, IL). Analysis of variance (One-Way ANOVA) was carried out to assess whether the different experiments conducted to statistically different results for those variables evaluated, pairwise comparisons of mean values using Tukey tests were also done. Simple Linear Regression was used to find correlation between peptides and their parental protein. Principal Component Analysis was performed to show where, in time, differences and similarities between experiments could be found during hydrolysis.

\section{Results and discussion}

\subsection{Chromatographic profile of hydrolysates}

Both the disappearance of $\alpha-\mathrm{La}, \beta-\mathrm{Lg}$ and the appearance of peptides were followed as a function of time. Hydrolysis with trypsin leaded to the formation of seven major peptides with different polarities. Similar qualitative profiles were obtained for the three experiments. Typical chromatograms for experiment B are presented in Fig. 1.

The average retention times for the 7 major peaks, designated $\mathrm{T} 1$ to $\mathrm{T} 7$ in order of increasing times, were $18.8,22.4,23.6,25.9,26.5,29.4$, and 31.7, respectively. Most of the relative areas of these degradation products increased on further hydrolysis up to $5 \mathrm{~h}$ approximately. It was possible to express results in terms of: (i) percentage of degradation of $\alpha$ - $\mathrm{La}$ and $\beta$ - $\mathrm{Lg}$ during hydrolysis time (Fig. 2); (ii) peptide formation during hydrolysis, through normalized chromatographic areas, given in

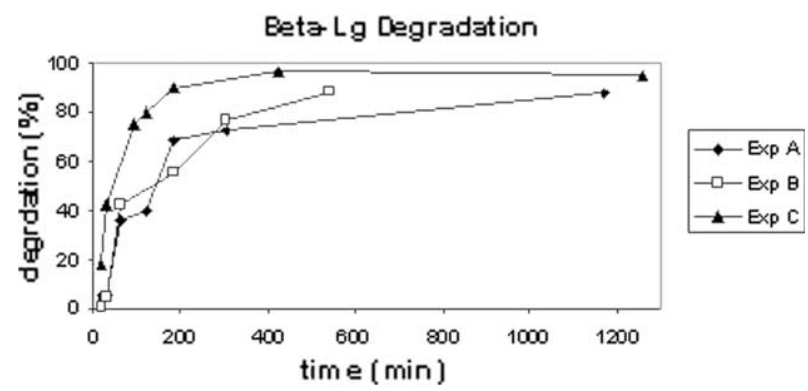

Fig. 2. Evolution of $\beta$ - $\mathrm{Lg}$ degradation during trypsin hydrolysis for the three experiments.

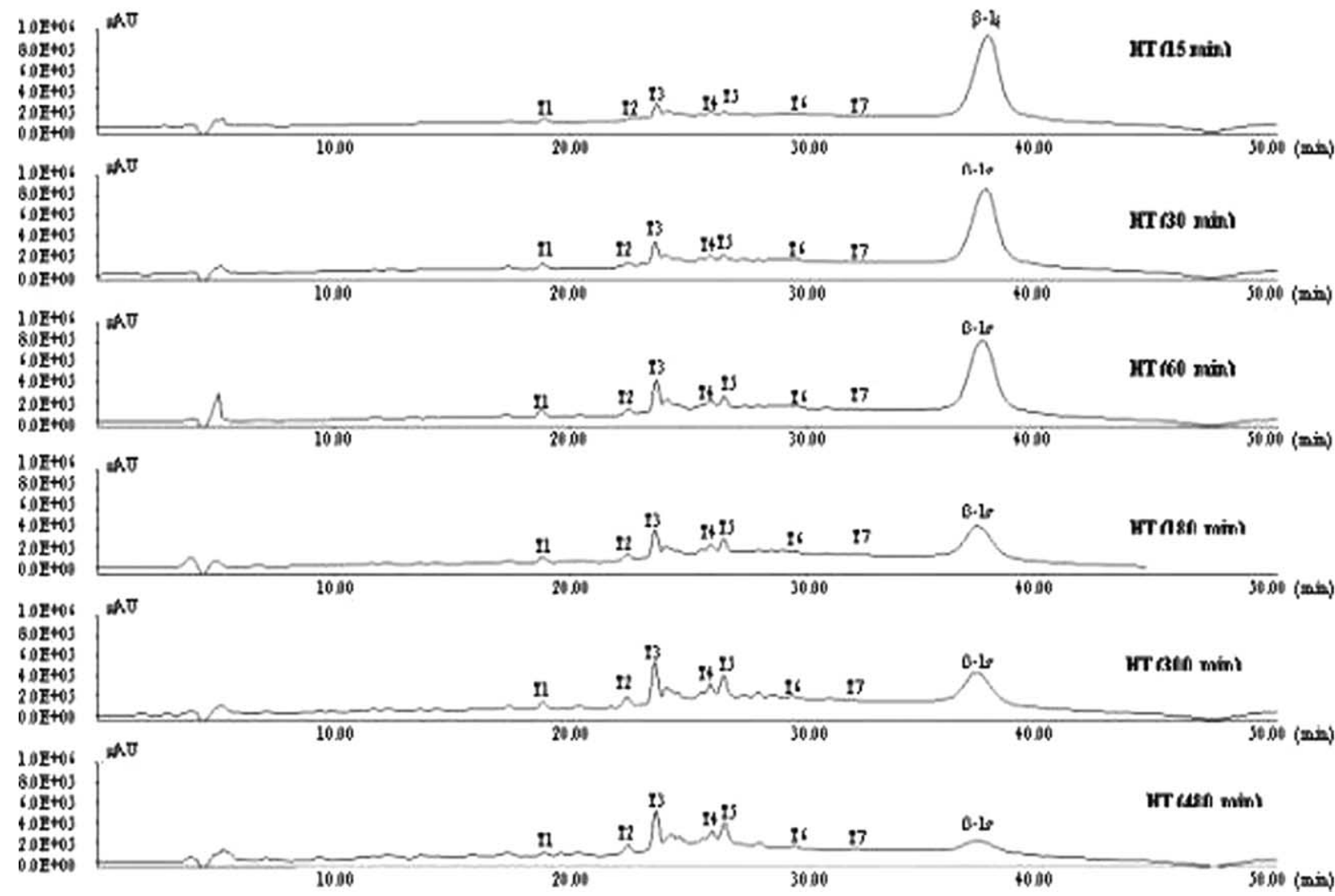

Fig. 1. Typical HPLC profiles of trypsin hydrolysates (480 min hydrolysis time). Seven major fractions were designated T1 to T7 according to the order of increasing retention times. 

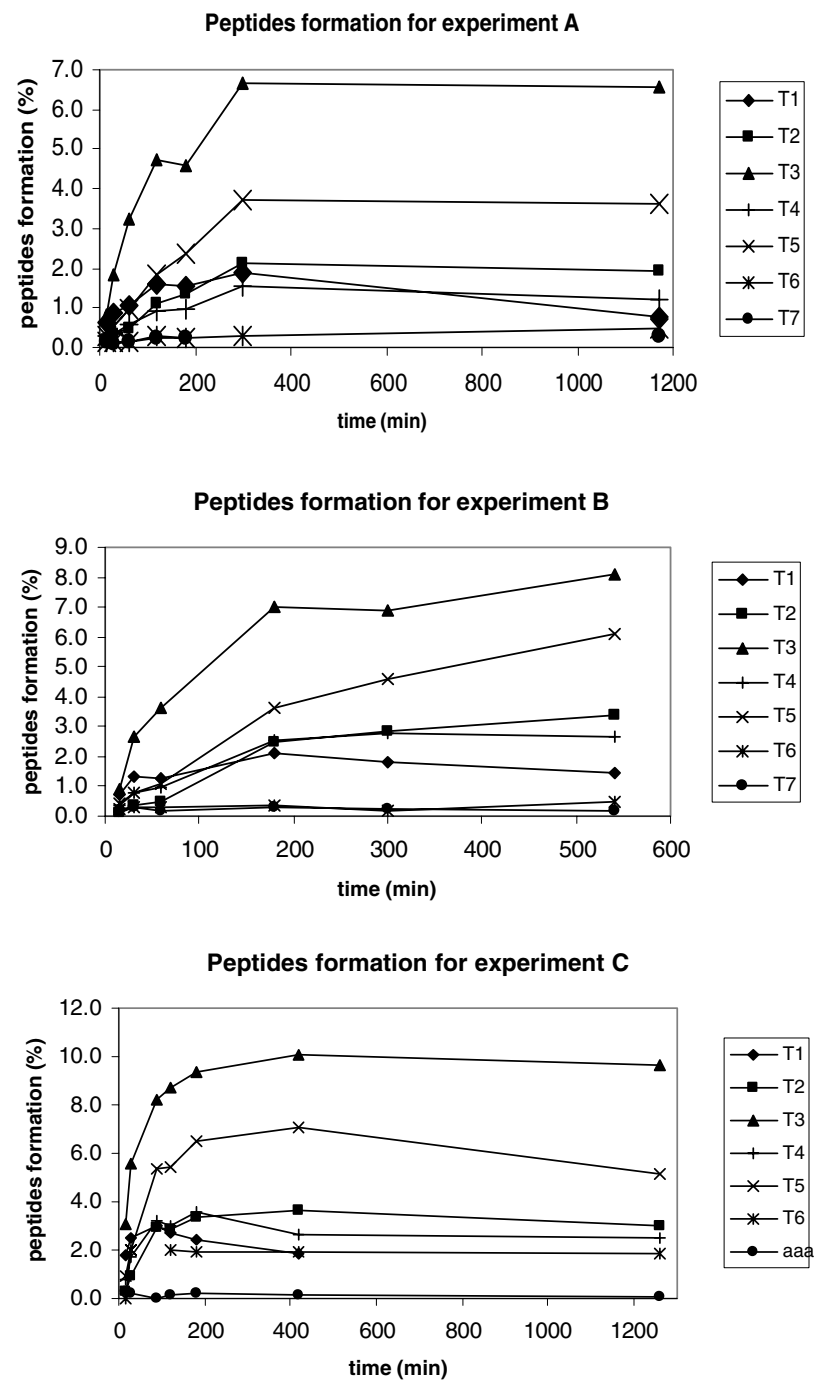

Fig. 3. Progress curves for peptide formation during trypsin hydrolysis for the three experiments.

percent of peak area of initial $\beta-\mathrm{Lg}$ (Fig. 3). It is interesting to point out that after $15 \mathrm{~min}$ of reaction for experiments B and C and 120 min of reaction for experiment A, trypsin hydrolysates presented a complete degradation of $\alpha$-La. In contrast, this did not occur for $\beta$ - $\mathrm{Lg}$, which degraded slowly and enabled to follow its disappearance and peptide release.

\subsection{Statistical analysis}

3.2.1. One-Way-ANOVA to assess whether the different experiments conducted to statistically different results for those variables evaluated

Statistical test One-Way-ANOVA was used, in order to verify whether the average values obtained, during time experiment, for each variable, $(\beta-\mathrm{Lg}$ degradation and percentage of peptides T1 to T7) could be considered different or not, for the three experiments. This

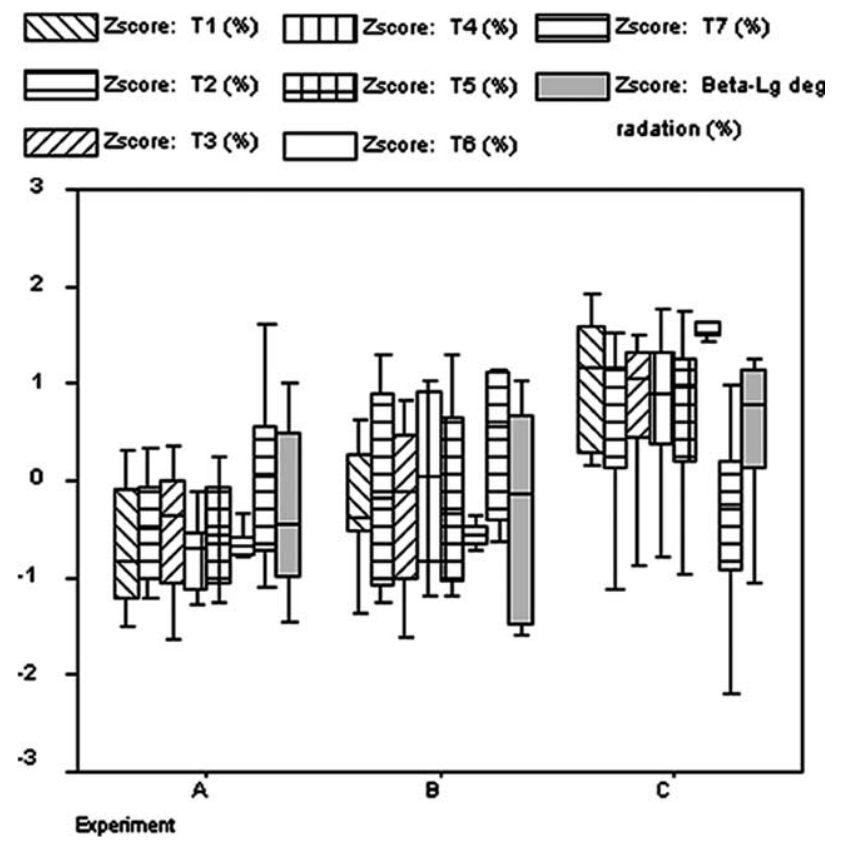

Fig. 4. Box plots representing standardized data distribution of variables used in One-Way-ANOVA.

was possible because data obtained as values, for each experiment (group), presented normal distribution (Shapiro-Wilk Test) and homocedasticity of variances (Levene Test) was observed. Box plots for each variable (standardized) are shown in Fig. 4. Results obtained for ANOVA and post hoc tests (Tukey HSD) are shown in Table 1. It was concluded, with $95 \%$ confidence, that there were no significant differences between experiments $\mathrm{A}$ and $\mathrm{B}$, (for $\beta-\mathrm{Lg}$ and peptides $\mathrm{T} 1$ to $\mathrm{T} 7$ ). Between experiments $\mathrm{A}$ and $\mathrm{C}$ differences were detected for peptides T1, T4 and T6. Thus, an increase of $\mathrm{pH}$ did not influence significantly the peptide formation; however, the increase of temperature increased significantly the amount of some peptides. This effect can be used to promote more extensive hydrolyse.

\subsubsection{Establishment of a correlation curve for the degradation of $\beta$ - $L g$ with hydrolysis time}

A correlation curve was established for the degradation of $\beta-\mathrm{Lg}$ with hydrolysis time (Fig. 5). As the variation observed was hyperbolic, the following equation was used for the model:

$\beta \mathrm{Lg}=a \times t /(b+t)$,

where $a$ and $b$ are constants; $\beta \mathrm{Lg}$ is $\beta$ - $\mathrm{Lg}$ degradation; $t$ is time.

In order to obtain these constants, the inverse of $\beta-\mathrm{Lg}$ values were plotted against the inverse of time values so that a linear representation could be obtained and constants calculated:

$1 / \beta \operatorname{Lg}=b / a \times 1 / t+1 / a$. 
Table 1

Results of One-Way-ANOVA and post hoc (Tukey) test

\begin{tabular}{|c|c|c|c|c|c|c|}
\hline Variable & Experiment & $N$ & Average $(\%)$ & Standard deviation $(\%)$ & $F$ & $p$ \\
\hline $\mathrm{T} 1$ & $\begin{array}{l}\mathrm{A} \\
\mathrm{B} \\
\mathrm{C}\end{array}$ & $\begin{array}{l}7 \\
6 \\
6\end{array}$ & $\begin{array}{l}1.19^{\mathrm{a}} \\
1.45^{\mathrm{a}} \\
2.37^{\mathrm{b}}\end{array}$ & $\begin{array}{l}0.48 \\
0.48 \\
0.49\end{array}$ & 10.49 & $\overline{0.001}$ \\
\hline $\mathrm{T} 2$ & $\begin{array}{l}\text { A } \\
\mathrm{B} \\
\mathrm{C}\end{array}$ & $\begin{array}{l}7 \\
6 \\
7\end{array}$ & $\begin{array}{l}1.08^{\mathrm{a}} \\
1.62^{\mathrm{a}} \\
2.43^{\mathrm{a}}\end{array}$ & $\begin{array}{l}0.78 \\
1.45 \\
1.30\end{array}$ & 2.30 & 0.131 \\
\hline $\mathrm{T} 3$ & $\begin{array}{l}\text { A } \\
\mathrm{B} \\
\mathrm{C}\end{array}$ & $\begin{array}{l}7 \\
6 \\
7\end{array}$ & $\begin{array}{l}4.06^{\mathrm{a}} \\
4.86^{\mathrm{a}, \mathrm{b}} \\
7.81^{\mathrm{b}}\end{array}$ & $\begin{array}{l}2.24 \\
2.87 \\
2.56\end{array}$ & 4.16 & 0.034 \\
\hline $\mathrm{T} 4$ & $\begin{array}{l}\text { A } \\
\text { B } \\
\text { C }\end{array}$ & $\begin{array}{l}7 \\
6 \\
7\end{array}$ & $\begin{array}{l}0.85^{\mathrm{a}} \\
1.69^{\mathrm{a}, \mathrm{b}} \\
2.50^{\mathrm{b}}\end{array}$ & $\begin{array}{l}0.46 \\
1.09 \\
0.95\end{array}$ & 6.44 & 0.008 \\
\hline T5 & $\begin{array}{l}\text { A } \\
\mathrm{B} \\
\mathrm{C}\end{array}$ & $\begin{array}{l}7 \\
6 \\
7\end{array}$ & $\begin{array}{l}1.90^{\mathrm{a}} \\
2.76^{\mathrm{a}} \\
4.64^{\mathrm{a}}\end{array}$ & $\begin{array}{l}1.39 \\
2.34 \\
2.29\end{array}$ & 3.30 & 0.062 \\
\hline T6 & $\begin{array}{l}\text { A } \\
\mathrm{B} \\
\mathrm{C}\end{array}$ & $\begin{array}{l}7 \\
6 \\
5\end{array}$ & $\begin{array}{l}0.25^{\mathrm{a}} \\
0.31^{\mathrm{a}} \\
1.95^{\mathrm{b}}\end{array}$ & $\begin{array}{l}0.13 \\
0.10 \\
0.07\end{array}$ & 457.72 & 0.000 \\
\hline $\mathrm{T} 7$ & $\begin{array}{l}\mathrm{A} \\
\mathrm{B} \\
\mathrm{C}\end{array}$ & $\begin{array}{l}6 \\
6 \\
7\end{array}$ & $\begin{array}{l}0.19^{\mathrm{a}} \\
0.22^{\mathrm{a}} \\
0.16^{\mathrm{a}}\end{array}$ & $\begin{array}{l}0.07 \\
0.06 \\
0.08\end{array}$ & 1.103 & 0.356 \\
\hline$\beta-\mathrm{Lg}$ & $\begin{array}{l}\text { A } \\
B \\
C\end{array}$ & $\begin{array}{l}7 \\
6 \\
7\end{array}$ & $\begin{array}{l}44.87^{\mathrm{a}} \\
44.77^{\mathrm{a}} \\
71.00^{\mathrm{a}}\end{array}$ & $\begin{array}{l}32.501 \\
36.43 \\
29.52\end{array}$ & 1.456 & 0.261 \\
\hline
\end{tabular}

${ }^{\mathrm{a}, \mathrm{b}}$ For each variable, average values without common superscript are significantly different $(p<0.05)$.

Linear functions presented acceptable correlation coefficients. Equation curves and the respective graphic representations for each experiment are presented in Fig. 5.

\subsubsection{Linear regression analysis to find correlation between peptides and their parental protein}

Trying to find out parental protein for peptides T1 to $\mathrm{T} 7$, simple linear regression, with $95 \%$ confidence, was used to obtain the degree of correlation between $\beta-\mathrm{Lg}$ degradation and the peptides released. The independent variable considered was $\beta-\mathrm{Lg}$ degradation and the dependent variables were each of the seven peptides evaluated.

Linear regressions were statistically validated and results are shown in Table 2. Peptides T2, T3, T4 and $\mathrm{T} 5$ are well correlated with $\beta$ - $\mathrm{Lg}$ degradation, for experiments $\mathrm{A}, \mathrm{B}$ and $\mathrm{C}$, with correlation coefficients $>0.85$, but the same was not observed for peptides T1, T6 and T7. In order to verify the significance of these results, analysis of outliers, resulting from this linear combination of variables was also carried out. Outliers were identified by verifying if one of the following three conditions occurred: absolute values for standardized residuals $>3$; absolute values for studentized residuals $>2$; absolute values for studentized deleted residuals $>2$. Effectively, in some cases outliers were detected and removed. Peptides T2, T3, T4 and T5 maintained or increased their correlation coefficients, confirming their dependence on $\beta-\mathrm{Lg}$ degradation. On the other hand, the peptides T1, T6 and T7 that were badly correlated with $\beta$ - $\mathrm{Lg}$ degradation, did not improve its correlation, indicating that these peptides were from $\alpha-\mathrm{La}$, or any other minor protein from whey. In order to confirm this supposition and, because $\alpha$-La was completely degraded soon after the beginning of experiments, data obtained at $15 \mathrm{~min}$ was removed for all experiments. In addition, data for experiment $\mathrm{A}$ at $30 \mathrm{~min}$ was also removed. Consequently, correlations between $\mathrm{T} 1, \mathrm{~T} 7, \mathrm{~T} 6$, and $\beta-\mathrm{Lg}$ degradation, became completely insignificant, confirming our supposition that these peptides have a parent protein that must be $\alpha$-La, or any other minor protein from whey.

\subsubsection{PCA analysis to find similarities and differences} between each analysis time for the three experiments

The extraction method principal components analysis (PCA) was used in order to study similarities and differences between each analysis time for the three experiments. Variables used were $\beta$ - $\mathrm{Lg}$ degradation and peptides related (T2, T3, T4, T5). Presuppositions for the application of PCA were evaluated: 


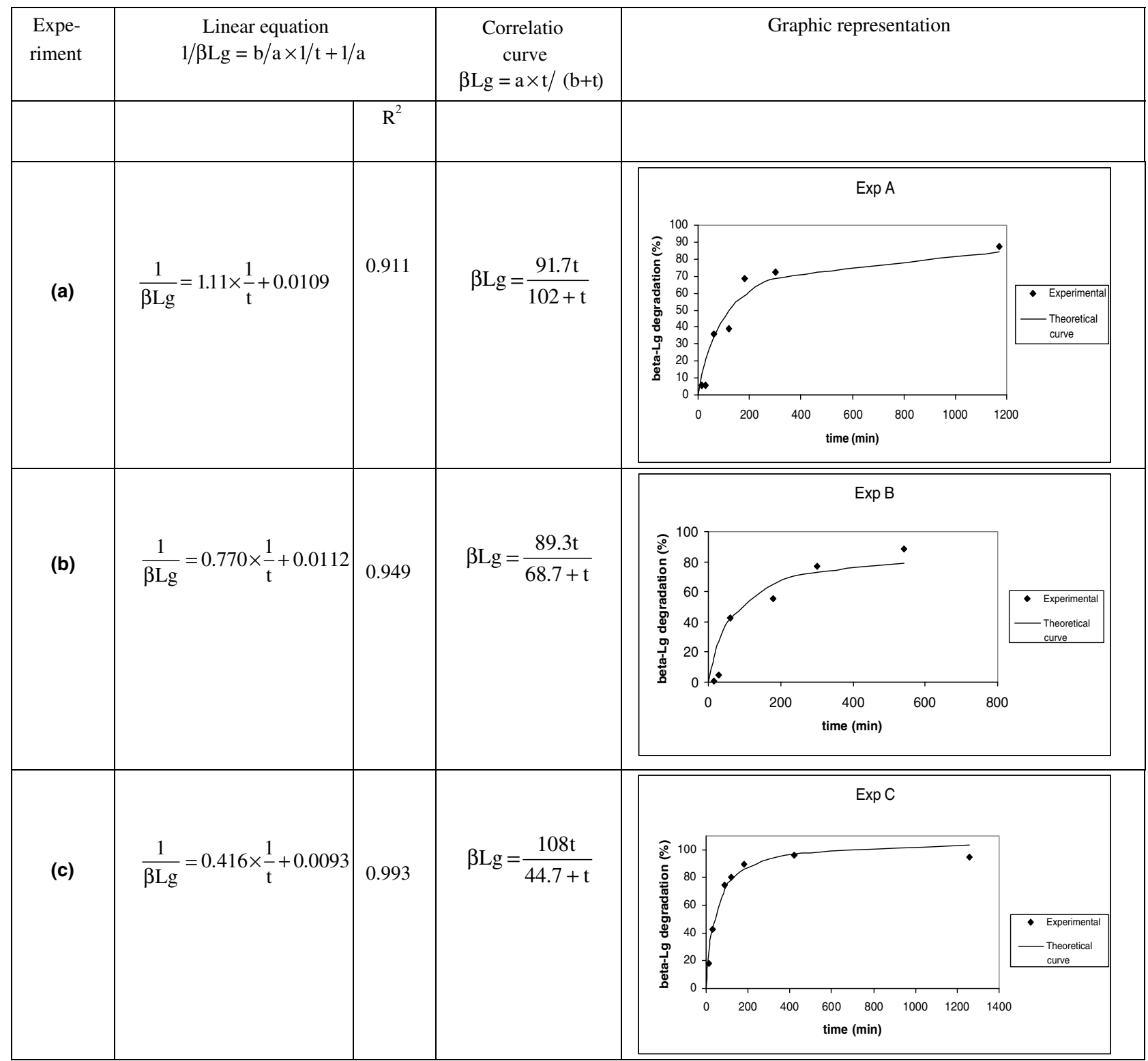

Fig. 5. $\beta$-Lg degradation as a function of time for the three experiments (linear functions, witch led the theoretical models, and respective graphic representations).

- Normality of data distributions was studied for each variable (Shapiro-Wilk Test, $p<0.05$ ). Not all variables had a normal distribution, but they were symmetric. (|skweness/standard error skweness $\mid<1.96$ ) and mesokurtic ( $\mid$ kurtosis/std. error $_{\text {kurtosis }} \mid<1.96$ ). Box plots for each variable (standardized) are shown in Fig. 6.

- Kaiser-Meyer-Olkin (KMO), measure of correlations quality between variables, was good $(\mathrm{KMO}=0.830)$, confirmed by Barttlett's Test of Sphericity $(p<0.05)$.

- Correlation matrix showed a good correlation between initial variables $>0.8$ (Table 3 ).

- Anti-image correlation matrix, which in the diagonal gives a measure of sample adequacy for each variable, also showed high values ( $>0.8$ in diagonal matrix's).
- Communalities which indicate the quantity of variables variance shared at least with one of the variables of the set, were also high (Communalities $>0.97$ ).

A new variable (factor one) was obtained with PCA, that explains most of the variance of initial variables $(94 \%)$. All five variables are associated with factor one. This factor together with factor two explains $98 \%$ of data.

A graphic representation relating these factors is shown in Fig. 7. From this representation three sets of analysis time points can be distinguished relating the different conditions to which the three experiments were submitted: 
Table 2

Results from linear regressions between each peptide and $\beta-\mathrm{Lg}$, for every experiment

\begin{tabular}{|c|c|c|c|c|c|c|c|}
\hline \multirow[t]{2}{*}{ Peptide } & \multirow[t]{2}{*}{ Experiment } & \multicolumn{3}{|c|}{$\begin{array}{l}\text { Straight line equation and determination } \\
\text { coefficient (by using all data obtained) } \\
(\mathrm{Pep}=a+b \times \beta \mathrm{Lg})^{\mathrm{a}}\end{array}$} & \multirow[t]{2}{*}{$\begin{array}{l}p \text { value for the } \\
\text { significance of coefficient } \\
a(t \text {-test; } p=0.05)^{\mathrm{b}}\end{array}$} & \multirow[t]{2}{*}{$\begin{array}{l}p \text { value for global } \\
\text { validation of the model } \\
(\text { ANOVA; } p=0.05)^{\mathrm{c}}\end{array}$} & \multirow[t]{2}{*}{$\begin{array}{l}p \text { value for verification of } \\
\text { normality of residuals } \\
\text { distribution }\end{array}$} \\
\hline & & $a$ & $b$ & $r^{2}$ & & & \\
\hline \multirow[t]{3}{*}{$\mathrm{T} 1$} & A & 0.89 & 0.01 & 0.20 & 0.04 & 0.31 & 0.70 \\
\hline & B & 1.07 & 0.01 & 0.42 & 0.04 & 0.16 & 0.56 \\
\hline & $\mathrm{C}$ & 2.05 & 0.01 & 0.09 & 0.02 & 0.56 & 0.80 \\
\hline \multirow[t]{3}{*}{$\mathrm{T} 2$} & A & 0.08 & 0.02 & 0.87 & 0.71 & 0.00 & 0.95 \\
\hline & B & -0.03 & 0.04 & 0.87 & 0.94 & 0.01 & 0.01 \\
\hline & $\mathrm{C}$ & -0.62 & 0.04 & 0.96 & 0.11 & 0.00 & 0.27 \\
\hline \multirow[t]{3}{*}{$\mathrm{T} 3$} & A & 1.16 & 0.06 & 0.88 & 0.09 & 0.00 & 0.67 \\
\hline & B & 1.52 & 0.07 & 0.90 & 0.09 & 0.00 & 0.74 \\
\hline & $\mathrm{C}$ & 1.66 & 0.09 & 0.99 & 0.00 & 0.00 & 0.47 \\
\hline \multirow[t]{3}{*}{$\mathrm{T} 4$} & A & 0.27 & 0.01 & 0.81 & 0.14 & 0.01 & 0.20 \\
\hline & B & 0.46 & 0.03 & 0.85 & 0.23 & 0.01 & 0.87 \\
\hline & $\mathrm{C}$ & 0.57 & 0.03 & 0.71 & 0.38 & 0.02 & 0.52 \\
\hline \multirow[t]{3}{*}{ T5 } & A & 0.07 & 0.04 & 0.90 & 0.85 & 0.00 & 0.69 \\
\hline & B & 0.07 & 0.06 & 0.88 & 0.92 & 0.01 & 0.05 \\
\hline & $\mathrm{C}$ & -0.63 & 0.07 & 0.92 & 0.44 & 0.00 & 0.11 \\
\hline \multirow[t]{3}{*}{ T6 } & A & 0.12 & 0.01 & 0.61 & 0.10 & 0.04 & 0.73 \\
\hline & B & 0.26 & 0.01 & 0.72 & 0.01 & 0.07 & 0.98 \\
\hline & $\mathrm{C}$ & 2.15 & -0.01 & 0.56 & 0.00 & 0.15 & 0.56 \\
\hline \multirow[t]{3}{*}{$\mathrm{T} 7$} & A & 0.12 & 0.01 & 0.79 & 0.01 & 0.02 & 0.37 \\
\hline & B & 0.21 & 0.000 & 0.05 & 0.01 & 0.68 & 0.12 \\
\hline & $\mathrm{C}$ & 0.29 & -0.000 & 0.40 & 0.01 & 0.13 & 0.11 \\
\hline
\end{tabular}

${ }^{a}$ Pep is peptide formed (\%); $\beta \mathrm{Lg}$ is $\beta$-Lg degradation (\%); $a$ is the intercept and $b$ is the slope; $r^{2}$ is the determination coefficient.

${ }^{b} p$ value for evaluation of the significance of intercept $a\left(H_{0}: a=0\right.$, the straight line has a zero intercept; $\left.H_{a}: a \neq 0\right)$.

c $p$ value for global validation of the model: $H_{0}: r^{2}=0$ (correlation coefficient is zero) or $b=0$ (slope is zero); $\mathrm{H}_{a}: r^{2} \neq 0$ or $b \neq 0$. 


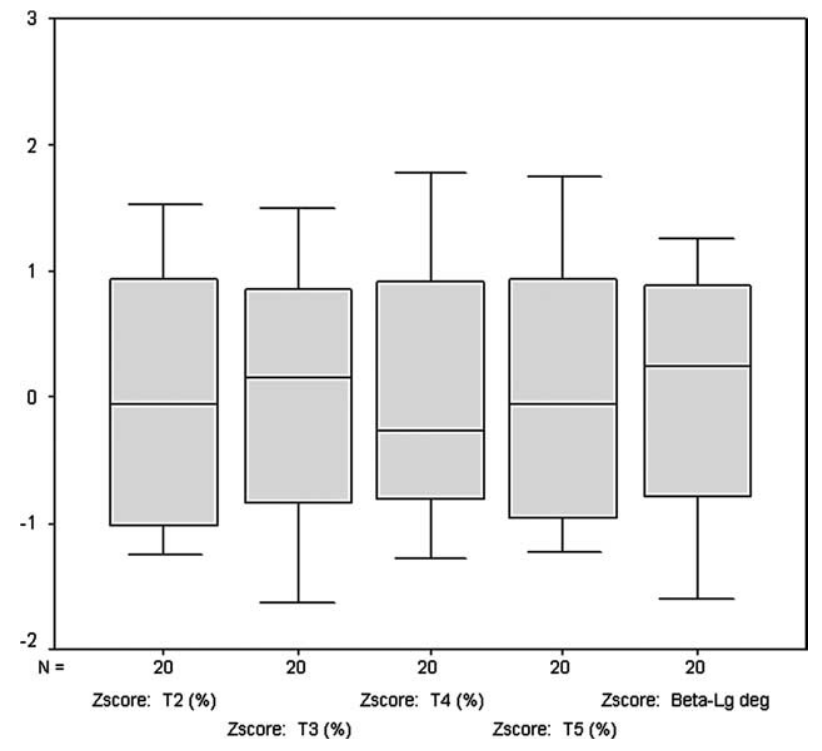

Fig. 6. Box plots representing standardized data distribution of variables used in PCA.

Table 3

Correlation matrix

\begin{tabular}{llllll}
\hline & T2 (\%) & T3 (\%) & T4 (\%) & T5 (\%) & $\begin{array}{l}\beta \text {-Lg } \\
\text { degradation } \\
(\%)\end{array}$ \\
& & & & & \\
\hline Correlation & & & & & \\
T2 (\%) & 1.000 & 0.958 & 0.929 & 0.990 & 0.918 \\
T3 (\%) & 0.958 & 1.000 & 0.916 & 0.963 & 0.940 \\
T4 (\%) & 0.929 & 0.916 & 1.000 & 0.928 & 0.809 \\
T5 (\%) & 0.990 & 0.963 & 0.928 & 1.000 & 0.917 \\
$\beta-$ Lg degradation & 0.918 & 0.940 & 0.809 & 0.917 & 1.000 \\
$\quad(\%)$ & & & & & \\
\hline
\end{tabular}

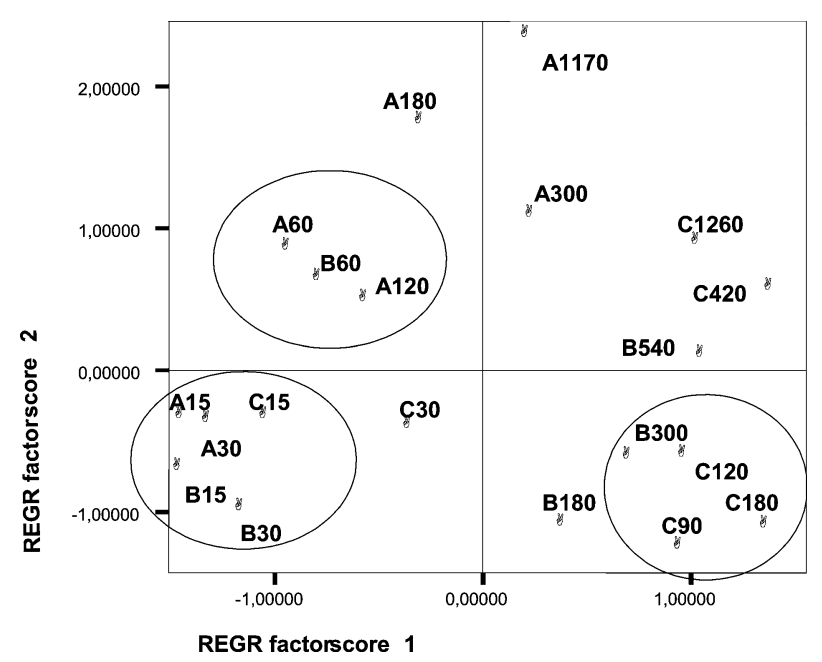

Fig. 7. PCA graphic representation of extracted variables, factors one and two. Variables used were $\beta$ - Lg and correlated peptides (T2, T3, T4 and T5).
- Set one clusters points from experiments A and B until 30 min hydrolysis time and only one point from experiment $\mathrm{C}$ at $15 \mathrm{~min}$.

- Set two contains points from experiment A and B at $60 \mathrm{~min}$ and from A at $120 \mathrm{~min}$.

- Set three contains intermediate points from both experiments $\mathrm{B}$ and $\mathrm{C}$.

\section{Conclusions}

One-Way ANOVA showed significant differences between experiments A and C. However, between A and B and between $\mathrm{B}$ and $\mathrm{C}$ differences were not significant. PCA analysis permitted to confirm this conclusion, by graphically evidencing where differences and similarities between experiments could be found during hydrolysis. Only at the beginning of hydrolysis (15 min), results from experiment $\mathrm{C}$ can be said similar to those of $\mathrm{A}$ and $\mathrm{B}$. After this time, experiment $\mathrm{C}$ could not be found together with experiment A. However with experiment B some approximation could be observed at intermediate times.

Summarising, it can be concluded that the hydrolysis process of whey with trypsin did not conducted to different results by just increasing $\mathrm{pH}$, from 8 to 9 , and maintaining a constant temperature of $37^{\circ} \mathrm{C}$. However an elevation in temperature from 37 to $50^{\circ} \mathrm{C}$, by maintaining $\mathrm{pH} 8$, can be advantageous when quicker hydrolyses is pretended.

Peptides T2, T3, T4 and T5 result from $\beta$-Lg degradation. Further separation of these peptides and identification of amino acid composition will be performed, because it can bring important information for food and pharmaceutical industry. To be used as ingredients in dietetic and in functional foods or in pharmaceutical products, these peptides should be hypoallergenic, present high nutritional value and appropriate organoleptic characteristics.

Moreover, with these statistical techniques a multitude of data was analysed simultaneously, which allowed for investigating correlations between several hydrolysate characteristics that are responsible for its functional and structural properties, influencing, for example, their rheology. The results of our study enabled further comparison of gelation, emulsifying and foaming properties of hydrolysates that clustered together, and also comparison between groups of hydrolysates that presented different characteristics, for a rational fractioning of whey proteins enabling an appropriate, fast and economic selection of ingredients on food and pharmaceutical industry.

\section{Acknowledgment}

This work received financial support from Fundação para a Ciência e a Tecnologia (Project POCTI/2000/ QUI/36452). 


\section{References}

Chen, S. X., Swaisgood, H. E., \& Foegeding, E. A. (1994). Gelation of $\beta$-lactoglobulin treated with limited proteolysis by immobilized trypsin. Journal of Agriculture and Food Chemistry, 42, 234-239.

Clare, D. A., \& Swaisgood, H. E. (2000). Bioactive milk peptides: a prospectus. Journal of Dairy Science, 83, 1187-1195.

FitzGerald, R. J., \& Meisel, H. (2000). Milk protein-derived peptide inhibitors of angiotensin-I-converting enzyme. British Journal of Nutrition, 84(Suppl. 1), S33-S37.

Foegeding, E. A., Davis, J. P., Doucet, D., \& McGuffey, K. (2002). Advances in modifying and understanding whey protein functionality. Trends in Food Science and Technology, 13, 151-159.

Korhonen, H. (2002). Technology options for new nutritional concepts. International Journal of Dairy Technology, 55(2), 79-88.
Leppala, A. P., Rokka, T., \& Korhonen, H. (1998). Angiotensin I converting enzyme inhibitory peptides derived from bovine milk proteins. International Dairy Journal, 8, 325-331.

Madsen, J. S., Ahmt, T. Ø., Otte, J., Halkier, T., \& Qvist, K. B. (1997). Hydrolysis of $\beta$-lactoglobulin by four different proteinases monitored by capillary electrophoresis and high performance liquid chromatography. International Dairy Journal, 7 , 399-409.

Otte, J., Ju, Z. Y., Faergemand, M., Lomholt, S. B., \& Qvist, K. B. (1996). Protease-induced aggregation and gelation of whey proteins. Journal of Food Science, 61(5), 911-915.

Shah, N. P. (2000). Effects of milk-derived bioactives: an overview. British Journal of Nutrition, 84(Suppl. 1), S3-S10.

Silvestre, M. P. C. (1997). Review of methods for the analysis of protein hydrolysates. Food Chemistry, 60, 263-271. 